\title{
September 11 and Middle Eastern Women: Shrinking Space for Critical Thinking and Oppositional Politics
}

\section{Haideh Moghissi}

ike millions of people who watched the horrifying events of September 11 live on television, my immediate reaction and thoughts were, who did it? What kind of a mind planned this? What was being sought by taking the lives of so many innocent people? Terrified, confused, and overpowered by the enormity of the crime, one could hardly think of the immediate social and political consequences of the tragedy for specific groups of people or consider that September 11 would become the subtext of a world politics justifying notorious racist domestic policies and aggression abroad.

Much has happened since. The hysterical reaction of the U.S. government, with its imposition of severe restrictions on the liberties of its terrified citizens, its extensive buildup of intelligence and surveillance apparatuses, its racial and ethnic profiling, its widespread questioning and detention of individuals of Middle Eastern origin and blockage of their bank accounts or businesses, and its wars on Afghanistan and Iraq, menacingly points to the path ahead. Canada did not go the same path, at least not for long and certainly not with the same intensity as its neighbor. But it is the United States that sets the tone for world politics. And in any case, numerous villainous attacks on Canadian citizens who were or were perceived to be from the Middle East immediately after September 11 and the continuous racist depiction of the Middle East, and of Islam and Muslims, by the Canadian media, too, have done much harm to the sense of belonging of individuals and communities of Middle Eastern origin. The message is clear. Having lived long in the country and obtaining citizenship, having built a home and raised a family here, does not make you a Canadian or U.S. citizen with the same democratic rights, legal protections, and life options as white citizens of European origin.

Longer versions of this piece were presented at the Swedish PEN and Writers' Association, Stockholm, September 16,2002, and at the conference on the Seventh Annual Day in Applied Psychoanalysis, University of Toronto, October 5, 2002. I would like to thank participants at these gatherings for their comments. I would also like to thank Sneja Gunew for soliciting this piece and the editors of Signs for their helpful editorial comments.

[Signs: Journal of Women in Culture and Society 2003, vol. 29, no. 2]

(1) 2003 by The University of Chicago. All rights reserved. 0097-9740/2004/2902-0005 $\$ 10.00$ 
The celebrated national narratives of Western democracies-the rule of law, tolerance, and respect for democratic rights-have proved deeply flawed, partial, and superficial.

I feel that September 11 has harmed me personally, and I know that I am not alone in this. In fact, a feeling of shame and responsibility for the September 11 tragedy has been imposed on all citizens of Middle Eastern background. And this despite the fact that an overwhelming majority of us have escaped various forms of political or cultural repression in our home countries or the persecution of fundamentalist regimes that, ironically, until very recently were supported and nourished by foreign forces that now crusade under the banner of "antiterrorism." For me, President Bush's war cry that "you are either with us or with the terrorists" and John Ashcroft's unambiguous condemnation of all criticism of the administration as "giving ammunition to America's enemies" recall, poignantly, Ayatollah Khomeini's speeches and intimidation tactics against which I fought, unsuccessfully, and which forced me to choose exile. I feel that I am reliving the past. I watch in horror and see how in the name of national interests and national security the space for critical thinking and oppositional politics is shrinking for everyone, further empowering the right-wing forces and unleashing violent patriarchal religious zealots everywhere.

I would argue that this supposed "war on terrorism" is, in itself, a new form of terrorism. To see this we need to redefine terrorism to apply the term not only to those who use killing, assassination, and sabotage for specific political ends but also to those who use politically motivated means to terrify, silence, immobilize, and coerce into submission their domestic opponents. And we must stop applying the term terrorist only to those of whose actions we disapprove, not because of the action itself but because of who they are. Then one could say that what we are witnessing today in the United States and in many other places are internal cultural and political campaigns waged by self-righteous states against their own citizens. ${ }^{2}$ In the United States, university professors who call on their government to pay closer attention to its own foreign policies that instigate terrorist activities are listed for their supposedly un-American and unpa-

${ }^{1}$ See Neil A. Lewis, "A Nation Challenged: The Senate Hearing; Ashcroft Defends Antiterror Plan; Says Criticism May Aid U.S. Foes," New York Times, December 7, $2001,1$.

2 John V. Whitbeck, an international lawyer, considers terrorism as a wholly subjective term and argues that the choice about using the word is frequently based not on the act itself but on who is doing it to whom. See John V. Whitbeck, "'Terrorism': The Word Itself Is Dangerous," Global Dialogue 4(2):59-65. 
triotic stance, and a pro-Israel think tank tries to intimidate critics of the politics of the U.S. and Israeli governments by creating a "Campus Watch" Web site and listing "dossiers" for university professors and teachers. In Canada, you can be criticized and abused by the media because of your critical views of U.S. foreign policy, as was the case of Professor Sunera Thobani in British Columbia.

Ironically, this so-called war on terrorism has created even more hostile situations for oppositional politics in countries that are assumed to be enemies of the United States. In Egypt, one can be convicted and put in prison for taking a critical stance against the government, as has been the case for Professor Ibrahim at American University in Cairo and his colleagues. In Iran, speaking out against one's own government has always been a high-risk undertaking. The individual who voices opposition can simply disappear.

Within this context, I fear that the tragedy of September 11 has created conditions to shrink the space for counterpatriarchal struggle for those of us who are committed to social justice and gender equity in our societies, both within the Middle East and in diaspora. In the West, Middle Eastern women are caught up in overt and covert racist practices and policies such as the tightening of immigration policies, border controls specially targeting Middle Eastern potential migrants, and other exclusionary practices $^{3}$ as well as the anti-Muslim and anti-Islam propaganda by governments and the media in the West. At the same time, Middle Eastern women are pressured by members of their communities, who see women's challenges to traditional male-centered cultural and religious values and practices as ill-timed, misguided, and in the service of imperialism.

In Middle Eastern societies, feminist challenges face greater obstructions. The authoritarian regimes and self-aggrandizing political and religious leaders have found the best excuse for silencing all oppositional forces, including feminists, in the name of resistance to U.S. aggression and Western political and cultural hegemony. The new war on citizens has caused further tightening of the sphere for women as it drives women's movements in Islamic cultures underground, and it is these movements, perhaps more than any others, that need access to an open public sphere. Altogether, the "war on terrorism" has proved to be a cultural and political

\footnotetext{
${ }^{3}$ The most recent example of this is the enactment of the Border Security and Visa Entry Reform Act by the U.S. Congress in April 2002. The act prohibited the admission of people from Cuba, Iran, Iraq, Syria, Libya, and North Korea, despite the fact that so far the individuals accused of terrorism in the United States are from Egypt, Saudi Arabia, and Pakistan. The list has since expanded to include people from other Middle Eastern countries.
} 
disaster that feeds on violence and breeds greater violence. It must be challenged.

Department of Sociology, School of Social Sciences, Atkinson Faculty

York University I

\section{Exception as Rule: Profile of Exclusion}

\section{Sunera Thobani}

merica's response to September 11, the war on terrorism, marks a new phase in the exclusion of people of color from the Western liberal democratic project. Even as the war is presented to the world as a defense of democratic rights and freedoms, the U.S. administration is institutionalizing racial profiling as a domestic security measure. Liberal democracy makes claims to the equal treatment of individuals before the law, but such profiling singles out individuals as suspicious on the basis of their "race," subjecting them to increased surveillance and control. While such profiling is being lauded as "a valuable tool of law enforcement," it brings to the fore the historically problematic relationship of people of color to Western democracy. ${ }^{1}$ Racial profiling reveals, once again, the fundamental character of liberal democracy as a racialized project.

As a modern form of governance, liberal democracy is said to be distinguished by its adherence to law and the juridical order. However, if we agree with Giorgio Agamben that the paradox of sovereignty is that the sovereign stands "at the same time, outside and inside the juridical order" with "the power to suspend the validity of the law," one could argue that September 11 was a moment wherein the sovereign suspended

I would like to thank Sneja Gunew as well as the reviewers and editors for their comments.

${ }^{1}$ John Ibbitson, "Why Racial Profiling Is a Good Idea," Globe and Mail (June 3, 2002). As a number of people have argued, the colonization of aboriginal peoples and the enslavement of black peoples are major underpinnings of the development of democracy in North America. See, e.g., Howard Zinn, A People's History of the United States (New York: HarperCollins, 1990); Ronald Wright, Stolen Continents: The "New World" through Indian Eyes (Toronto: Penguin Books, 1990). 